\title{
China's Internationalized Higher Education During Covid-19: Collective Student Autoethnography
}

Michael A. Peters ${ }^{1} \cdot$ Hejia Wang ${ }^{1} \cdot$ Moses Oladele Ogunniran ${ }^{1}$. Yingying Huang ${ }^{1} \cdot$ Benjamin Green ${ }^{1}$ - Jasmin Omary Chunga ${ }^{1}$. Eric Atta Quainoo ${ }^{1}$ - Zhihong Ren ${ }^{1}$. Stephanie Hollings ${ }^{1} \cdot$ Chunxiao Mou $^{1}$. Sphiwe Wezzie Khomera ${ }^{1}$ - Man Zhang ${ }^{1}$ • Shuchen Zhou ${ }^{1} \cdot$ Amina Laimeche $^{1}$. Wener Zheng ${ }^{1} \cdot$ Rulin $\mathrm{Xu}^{1} \cdot$ Liz Jackson $^{2} \cdot$ Sarah Hayes $^{3}$

Published online: 8 May 2020

(C) Springer Nature Switzerland AG 2020

\begin{abstract}
This article presents 15 autoethnographical texts detailing student experiences at Beijing Normal University in the midst of the Covid-19 pandemic. Contributions have been collected over 6 weeks between 15 February and 1 April 2020, edited by Hejia Wang (assisted by Moses Oladele Ogunniran and Yingying Huang), and supervised by Michael Peters. Through shared in-depth empirical feelings and representations from a wide variety of cultural, historical, and social contexts, the article outlines an answer to the question: How do students, connected virtually but separated physically in an internationalized university, deal with disruption brought about by the Covid-19 pandemic? Student testimonies offer reflections on Covid-19 and Chinese international education, experiences of online teaching and learning, reflections on university coping mechanisms, an account of realities and feelings related to changes in academic life, and discussions on coping strategies in Chinese international higher education. Contributors expose their individual feelings, effects, benefits, challenges, and risk management strategies. Collected at the peak of the Covid-19 pandemic, these testimonies are unable to offer systemic answers to challenges facing the whole world. However, these experiences and feelings will provide important inputs to global discussions about the future of the world, after Covid-19.
\end{abstract}

Keywords Covid-19 $\cdot$ Pandemic $\cdot$ Challenges and opportunities $\cdot$ Collective autoethnography $\cdot$ International higher education $\cdot$ China

Hejia Wang

wanghejia@bnu.edu.cn

Extended author information available on the last page of the article 


\section{Introduction (Hejia Wang)}

Up until very recently, worldwide higher education (HE) has lived a dream of prosperous global exchange and sustainable development. Nonetheless, this dream is merely a toddling brainchild of education leaders and policymakers which wobbles around the cliffs of regional wars and conflicts, famines, natural disasters, pandemic diseases, and other threats. International education is growing in size, but not necessarily in strength; in the increasingly connected world, our interdependency puts us at a higher risk of disruption and unease. The Covid-19 pandemic has brought about enormous hindrance to the internationalization of higher education (IHE) in our increasingly globalized, yet divided, world.

An old argument has it that globalization creates demand for internationalization of higher education, which, in turn, benefits global society (DeWit 2020; Altbach 2013; Zha 2003; Knight 2004; Altbach and Knight 2007). However, this definition of IHE has been repeatedly broadened. In the early 1990s, definitions of IHE challenged previous interpretations for their instrumentalism, and emphasized internationalization as a set of integrated measures which incorporate the international dimension in an institution's primary functions, such as teaching, research, and social services (Knight 1993; Zha 2003). Later definitions highlighted that internationalization should be an intentional tool to serve global development goals and foster international partnership and cooperation rather than competition (Van Der Wende 2001). More recent reflections on IHE focus on post-hegemonic academic development, the use of English as the lingua franca, inclusiveness, and tensions between commercial competition under marketization versus intellectual collaboration for quality improvement (Knight 2012; DeWit 2019). In the context of modern nationalism of North America and countries in continental Europe, many are concerned about neoliberal commodification (Marinoni and DeWit 2019), and some scholars identify new critical players in IHE such as China (Altbach and DeWit 2017).

China, whose IHE has been lucrative to many universities but whose theoretical and systematical framework is elusive to many western scholars, seems to be one of the epicenters of such disruption. China's IHE is rapidly changing in its fast-growing economy and in a unique socio-political context (Zheng and Kapoor 2020). Under China's adaptive governance approach in policymaking (Heilmann and Perry 2011), the nation continually adjusts its governance strategy (Lim 2017) as a means to experiment with innovative policies to build state and university consensus (Han 2020). Grown from a long tradition of totalitarian instrumentalism, China's state government remains an essential authority in educational systems. At the same time, it relinquishes from direct supervision of IHE, providing universities and the private sector with high levels of autonomy within set boundaries (Han and Xu 2019; Yang et al. 2007; Zha 2012). These various stakeholders are still far from striking a balance, yet due to its size and influence, China's IHE is a global player worthy of attention. According to the Ministry of Education of the People's Republic of China (2019a, b), in 2018 China had over 492,000 international students from 196 countries studying in 31 provinces, and over 662,100 Chinese students abroad — almost all of which have not received government or institutional funding (Ministry of Education of the People's Republic of China 2019a, b). 
In the spring of 2020, a new disease struck the world like a tsunami. Within less than 90 days from its official identification in late January, the 2019 novel coronavirus disease (Covid-19) has affected over 294 thousand people in 187 countries (World Health Organization 2020), bringing cities and transportation into shutdown, people quarantined at home, and worldwide nations into war-time measures. Yet the number of confirmed cases and deaths continues to climb upwards globally even when it starts to climb downwards within China (National Health Commission of the People's Republic of China 2020), leaving China now fighting to contain imported cases from overseas passengers alongside its own struggles to recover from a national shutdown.

Chinese universities are not immune to the disease, and the coping mechanism is multifold. Millions engage in online education (Ministry of Education of the People's Republic of China 2020a, b), and online learning has become a new norm despite initial discomfort and disconnect. Institutions have strict policies on personnel mobility, and many of them are in full lockdown. International and Chinese students planning international travel are facing difficult choices. Many international students went back to their home country, thinking they could return after the Spring Festival break when the disease gets under control, but are now facing outbreaks in their home countries and strict global travel and custom restrictions. International students who remained in China are self-quarantined in their homes or on campuses, and Chinese students are advised against traveling to other countries. Traditional academic life, in general, is heavily disrupted. Although 2 months of stringent measures have effectively brought down the number of new cases of Covid-19 to zero in provinces outside of Wuhan, China slowly and carefully introduces measures for returning to normal life.

This article explores the disruptive impacts of the Covid-19 pandemic to Chinese IHE from a political and socially conscious qualitative standpoint (Ellis et al. 2011). Such exploration is neither based on obsolete numbers distanced from feelings and reflections of participants, nor on the perspective (including language) of one researcher. Abolishing the master narrative and embedded paradigms induced from researchers (Kuhn 1962/2012), and resisting potential colonialist culture exploitation in traditional ethnography (Ellis 2007), our collective autoethnography approach welcomes selfconsciousness and personal values that are meaningfully grounded in first-hand experiences, hence highlighting the importance of authors' subjectivity and emotions to the story (Bochner 2002).

This article reaches beyond a collection of disconnected personal stories and opens up opportunities to use theoretical and methodological tools of scholarly literature to illustrate shared facts through individual stories. Exploring personal stories and inward reflections of IHE participants during Covid-19, this article presents 15 autoethnographical pieces detailing student experiences as active participants of China's current IHE under the pandemic. Student contributions have been collected over 6 weeks between 15 February and 1 April 2020, edited by Hejia Wang (assisted by Moses Oladele Ogunniran and Yingying Huang), and supervised by Michael Peters. Through shared in-depth empirical feelings and representations from a wide variety of cultural, historical, and social contexts, the article outlines an answer to the question: How do students, connected virtually but separated physically in an internationalized university, deal with disruption brought about by the Covid-19 pandemic? 


\section{Covid-19 and International Education}

\section{International Education During a Semi-Apocalyptic Viral Pandemic (Benjamin Green)}

At first, news spread slowly, with some reports saying that the virus could not be spread by human-to-human contact. However, as was later found, it became clear that local government officials had failed to properly assess and report the extent of the outbreak (Tufecki 2020). When word finally did spread to all corners of the nation, it was too late. Thousands upon thousands of citizens would become infected, with the world's largest annual migration helping to cement Covid-19 as a certified global pandemic. This annual migration, known as the Spring Festival in China, is a time when families ceremoniously go back to their hometowns for, often-times, the only visits they will pay their relatives during the year. Ironically, for many, this visit, which usually lasts no more than one to 2 weeks, has now been prolonged indefinitely. As millions of families anxiously wait, confined to their homes, praying for news of a cure, or for that matter, any signs of abatement, the virus continues to spread across the globe. Each new day brings news of yet another country hit by the seemingly incurable, and devastatingly elusive Covid-19 virus, referred to colloquially as 'the coronavirus'.

It has been about a month and a half now since my January 17 th trip to Beidaihe, a trip that was supposed to be, as with many others, a 2-week trip to visit family before heading back to Beijing to prepare for the Spring semester. However, on around January $21 \mathrm{st}$, news started circulating about just how dangerous this virus was, with daily updates on the incredibly infectious nature of Covid-19 quickly turning a regional concern into a full-scale national emergency not witnessed since the SARS outbreak of 2004. Around this time, the government began to lock down not just Wuhan, the epicenter of the epidemic, but every city, prohibiting interprovince travel and confining netizens to their homes, with bands of local volunteers, reminiscent of the red guard militias of the past, ensuring that stringent new curfews are adhered to by all. It was almost surreal as images of Americans being evacuated from Wuhan swept across social media on January 29th. Many foreign nationals followed suit, catching last-minute flights out of the country, sometimes having to transfer multiple times to avoid travel bans enacted for passengers flying out of China. Some stayed, however, choosing, for one reason or another, to wait it out, placing outsized trust in our adopted homeland, hoping against hope that China's exceptional measures of containment could stem the rising tide of infection. For those of us not hailing from centralized nation-states, we cannot help but marvel at how efficiently China has managed the quarantine of its almost 1.4 billion citizens, hoping that our own countries can find their paths towards containing the spread to our families and loved ones overseas. So, we continued to wait, sometimes patiently, sometimes in desperation, frequently with a malaise that comes only hard-earned, from having not left your apartment for weeks on end, from the feeling of never knowing when this interminably cruel holiday might end.

Within a few weeks, those of us within China's field of HE, i.e., students, lecturers, etc., were met with messages from our respective university faculties. We were informed that, regardless of the continued national health emergency, 
without so much as a gap in scheduling, classes would continue as planned. The one caveat, all classes would now be held online. I wondered aloud, and not so politely, at how this would be possible. How could an entire nation take classes online? This was a government decision which touched every single level of education. From compulsory education at grade one, all the way up to Ph.D. level graduate courses, everything would now be held in one form of virtual classroom or another. My skepticism would need to be held in check, as of now, during the time of this writing, China's millions of students are studying online, to varying degrees of success no doubt, but studying online nonetheless. And I, an avowedly anti-online education professional, someone who more than once decried the need for a physical classroom as a medium for scholarly debate and socialization, find myself not just taking an online course, but teaching two as well. So I am now confronted with the task of undoing all of my prejudices and biases against the digital pedagogical revolution, hoping, praying that I can evolve quickly enough, and with enough acumen, to provide my students with an educational experience that overcomes the obstacles present within an education system grappling against a semiapocalyptic viral pandemic.

\section{Fragmented Resentment: Bias and Hatred Fueled by a Pandemic (Yingying Huang)}

With the spread of the Covid-19 controlled and the number of people recovered incrementally rising, Wuhan, the epicenter of the pandemic, is walking out of the lockdown from January 23rd. I cannot forget the moment when I saw the news about the lockdown. I was shocked because I traveled to Wuhan last summer with my boyfriend. I shared the story with him at once, and he said: 'it is bad'. Later on, as the news reached more people around the world, different interpretations and voices came up. One voice, by the influential newspaper The Guardian (Eve 2020), was that the lockdown was a massive authoritarian measure eroding human rights. Back in the day, I guess they could not see the irony-Covid-19 soon spread all over the world, and many countries have announced similar lockdown orders. For instance, Italy, which has an exceptionally large number of casualties, announced a nationwide lockdown on March 9th. Why could not they see that Covid-19 does not know borders, and that any place attacked by the disease, that did not respond quickly and effectively, would bear significant suffering?

Chinese overseas feel the direct impact of this politically fueled hatred. These days, some of my Chinese friends who are studying abroad get unwelcome treatments. Wearing a mask as self-protection brings them loads of hatred and fear. One of my friends in the UK was pointed at directly by a stranger who shouted: 'Coronavirus! This lady got the mask on!' Some of my friends believe this hatred and fear are due to cultural differences, while others view these are related to racist nationalism or xenophobia. International students, who are very vulnerable to these attitudes and behaviors, need more than ever to remain calm and rational. Fortunately, following the global spread of the pandemic, more and more people realize the necessity of wearing masks and know that Covid-19 is not a 'Chinese virus'. I do hope that will block the resentment stirred by those biased groups that fueled hatred among people from different countries. 


\section{Experiences of Online Teaching and Learning}

\section{Coronavirus and International Education (Chunxiao Mou)}

Between January 18th and mid-February, the first thing I woke up to every day was WeChat news and notifications of new cases in my area. The only topic discussed during that period was the coronavirus. Starting from January 26th, all residents in my community were not allowed to go out without exceptional circumstances. The community had only one open entry and one open exit, and also a 24-h epidemic monitoring duty. To go in and out, one had to wear a mask. I expected that the whole society would be paralyzed under the pandemic with no stores open, no cars or people in the street, but I underestimated the efficiency of the government's measures and people's determination to overcome difficulties. I can know the world without leaving home. In addition to TV reports and announcements of my school's online public account, news, opinions, and academic articles about the coronavirus are flooding social media platforms such as Weibo and WeChat.

I take classes, have Zoom meetings with my supervisor in Germany every Tuesday, and discuss with my classmates from all corners of the world. I have also taken up courses through Beijing Foreign Studies University's website, whose online language learning platform is open to the public and free of charge since February 1st. Its foreign language courses cover 20 languages, including online courses and resources supporting foreign language teaching and learning, international exams, and Culture General Education, etc. Those courses prepare people to be active and engaged participants in an interconnected and intercultural world, and to support the goal of international education to help students adapt to and address global challenges.

I expected that going online would be a tough challenge for teachers and students of kindergarten, elementary, and secondary schools, who are not so keen on high-tech teaching facilities and may be conservative in regard to online education. But I changed my view when I saw Nuo, my nephew, who was in her second grade of junior high school, having online classes every day. Fiveyear-old Yan, another nephew of mine, has been taking drama classes online with a British teacher. Both Nuo and Yan have school assignments and projects about coronavirus. I am amazed by their teachers' high levels of information literacy and adaptability to online teaching. People's acceptance of online education is getting increasingly high, and the speed of popularization of online education may exceed our imagination.

My elder sister, who is a mother of three children, has immersed herself in the joy of cooking and baking following her online cuisine lessons. Now we do not have only traditional Chinese cuisine such as dumplings and yuan xiao, but we also enjoy western food such as toasts, chiffon cake, sushi, pizza, pasta, and so on. Online education extends the reach of traditional educators, not only to students studying at schools but also to other groups such as homemakers. Online education can also provide more courses that might not be offered by ordinary Chinese schools, such as baking and drama. Learners, regardless of their nationality or social status, are now confined to their homes; online learning is accessible to them without discrimination. In unfortunate lockdown circumstances caused by Covid-19 pandemic, online learning and teaching are useful tools to boost international education. 


\section{Connectiveness During Separation: Online Education During Covid-19 Pandemic (Hejia Wang)}

In mid-February, it became clear to us all: this winter break will not end soon. Covid-19 made us all seriously prepare for online teaching and learning. Feelings are mixed, and everyone is on their toes. It is hard to focus on work when everything is up in the air. I find myself eager to return to my normal life and learn properly. But as a regular Joe renting an apartment in Beijing, there are many things I need to do before I return to my old regular life. I need to pay attention to city instructions; whether my community allows travel; how to keep myself safe on the way; how to self-quarantine; how to get essentials during selfquarantine; where to buy face masks; is there a ration for this or that product; and which online store is still making deliveries. I need to apply to my university not only for returning to campus but also for returning to Beijing. Things could never be as simple as they used to be.

For university staff, the workload for preparing online education is astounding, and the shift is not easy. Being an urban university, Beijing Normal University is notorious for a high population density, and we cannot afford community transmission. Yet, we already have confirmed cases of Covid-19. Suddenly everyone is alert, self-isolating, and looking frantically into online teaching and learning, but not everyone knows how to do it well. Faculty's TPACK (Technological Pedagogical Content Knowledge) is challenged most directly, but there are lots of heartwarming moments, like when faculty and staff are sharing all their resources and knowledge on group chat, fixing each other's technical hiccups, showing both theoretical backgrounds and applied experiences, trying out innovative measures for their cohort, and expanding their understanding.

As a student of online learning, I thought that I came prepared. I pride myself to be a semi-veteran of online teaching because I used to work as an online teaching instructor, developed tutorials and packages to help faculty teach online, am familiar with many online learning management systems and teleconference tools on the market, and I did research in online teaching pedagogy. How hard can it be for me? But I could not be more wrong! As it turned out, I could never be too prepared. When our cohort meets online, I can see the struggle. For instance, I struggle to find a convenient platform for sustained and threaded conversations. For now, we have a notice board, but that is of little meaning for going back and forth on our learning. I fear this will be the case for this entire class. Without structured study and work-life structure, I am consistently close to missing deadlines, trying to balance work and research.

We, staff working on university internationalization, are heartbroken with the pandemic. International students are leaving one by one; we are tracking down and checking up our faculty members and students in foreign countries, making sure they are safe. Planned international travel gets canceled until May; we write to our partners and cancel events and bookings. However, I believe that these are only temporary, emergency measures, and that our international ties will not weaken. 


\section{Reflections on the University's Coping Mechanisms}

\section{The Dilemma of International Students in the Outbreak of Coronavirus (Jasmin Omary Chunga)}

It all started in December 2019, at the end of the first semester. Every international student had his/her plan during vacation; some wanted to visit different places, and others planned to go back to their home countries. Unfortunately, the Covid-19 outbreak caused tension, fear, panic, and dilemmas to international students; many of their plans missed the mark, especially for those who remained in China.

Beijing Normal University was brought to a halt. International Student Affairs kept in touch with love and support to international students, emphasized and admonished the need to stay indoors, avoid crowds and gatherings; some campus gates closed to ensure security. International students who were away from campus received notices which prohibited them from returning until further notice. On-campus international students faced a challenge whether to go back to their countries. We had no idea when novel coronavirus threat might come to an end. Things continued to worsen, we were told to stay indoors, and shops were closed — we had only one open supermarket, which hardly had all the products we needed. Most of the restaurants closed as well, the one open restaurant offered food which was not to everyone's tastes.

We now follow online classes. Some international students (especially those who are in their home countries) face network problems, and time difference is a challenge. We are praying that this crisis will come to an end soon. Medical doctors and the Chinese government are looking for a solution day and night. As parents lose their children, children lose their parents as well; it is so painful and we are crestfallen.

\section{The Impact of Novel Corona Virus on International Students' Life (Eric Atta Quainoo)}

The novel coronavirus epidemic quickly accelerated and spread through China, killing more than 4000 people. The epidemic has pushed China's health system beyond its capacity, bringing the country into intense additional stress and ultimately forcing school closures. Public gatherings were banned, including lectures, and various restrictions have been imposed on students' freedom of movement, entertainment, and socialization. The university temporarily isolated suspected cases, and that caused additional stress. One international student described her experience of stigmatization that she experienced after the quarantine: fellow students in her dormitory were afraid of the virus, and they would not touch her and even talk to her. She felt hurt and responded by isolating herself from her friends. This incident reveals vulnerability in the school communities' capacity to recognize the specific stresses and losses of those quarantined.

School closure fueled fear and mistrust, and school reopening is delayed by the Ministry of Education. At the height of the epidemic, important resources had to be diverted from education to health emergency response programs. A robust emergency plan has been developed by all universities and colleges; online and distance learning programs are strongly encouraged. Students have noted various emotional impacts of the outbreak; many report a profound feeling of loneliness due to the ban on public 
gatherings. Some of my friends expect a rise of depression and anxiety disorders in post-novel-coronavirus China. However, the university does provide a social service support system to help students through the closure of the university. The Chinese Government, the Ministry of Health, and the international community are working together to figure out how to combat such an outbreak. We pray and hope that the novel coronavirus epidemic will be over soon.

\section{How Chinese Universities Supervise International Students During the Spread of Covid-19 (Zhihong Ren)}

At the end of January, novel coronavirus cases were detected in Wuhan City and many other areas. Teachers and instructors tried their best to ensure the safety and health of every student. Here are some of the requirements:

International students who live on campus or off campus or travel in other cities of China during the winter vacation have to report their location and their temperature to their counselor every day. If students have been to Wuhan recently, or in close contact with students who have been to Wuhan, they need to inform their counselor. Students who live on campus must pay attention to the hygiene and ventilation of their rooms. They were asked to stay in their room, do not leave the campus. If they need to go out of the dormitory, be sure to wear a mask and take their student card and go to the dormitory reception registration. Students who live off campus have to stay at home and try not to meet with people, especially to avoid social gatherings. Students who live on or off campus should reduce the frequency of going out for shopping. Teachers suggest that some representatives help other students to go to the supermarket to minimize the risk. Wash hands frequently! Wear masks outdoors! Disinfect timely! Exercise and a proper diet will help students enhance their immunity and stay healthy. If there are any suspected symptoms, such as a cough or a fever, go to the hospital and get medical treatment immediately and then report to their counselor. During the period of epidemic prevention and control, Chinese teachers and administrators help international students in daily disinfection to ensure the safety and health of every student.

Unfortunately, the discrimination against Chinese people around the world spread with novel coronavirus. International students from China are also involved. When Chinese teachers do their utmost to look after international students from all over the world, Chinese students are discriminated against and excluded due to a narrow, limiting, and parochial view. I wish the world could unite together and fight against the novel coronavirus with some real action.

\section{Changes in Academic Life}

\section{Research in the Time of COVID-19 (Stephanie Hollings)}

There were many reasons for me to choose to undertake a Ph.D. in China, one of the main ones was being able to finish the imposing process in 3 years, while in my home country of the USA, a Ph.D. generally takes a few more years. What I have learned since coming to China, is that if one wants to finish that journey in 3 years, a strict timeframe must be adhered. The first year is predominately about taking courses and 
being a student. The second year should be marked by two distinct milestonespreparing a proposal and successfully defending it (happening hopefully in the first semester) and the beginning of the research phase, where the identity of the student switches to that of the researcher (second semester).

For those like me, a second year Ph.D. student in China, an unexpected hurdle was thrown into the mix of our carefully scheduled timeframe. Covid-19 became the latest virus to rear its ugly head against humanity. I, like many others, had plane tickets to go back home, and there I would wait for news in the upcoming semester. As the Spring semester drew ever closer, I waited in anticipation for when I could go back to China. Yet, here it is, March and I am still in the USA, unable to return until my university says I can.

Yet, the university continues with online classes, daily check-ins on temperature, and emails from the university, but what is ignored is the disruption caused. The impact of the coronavirus can be quantified by the loss of profits for universities, but how to quantify in terms of students' loss and their ability to do research?

As I am a human being, I am inherently selfish, and keep returning to the thought of my own research, which is now on hiatus, thus making me a researcher-on-hiatus, a far cry from what I should be, if I am to finish in 3 years. My whole proposal centered around China and the unique position of international schools in China. Instead of traveling throughout China with my supervisor, to understand the international school experience, I am sitting at home, thinking of this pause. As a friend pointed out, even if I tried to do this online, the student's answers would be reflexive of their own recent experiences with Covid-19, creating a whole new dynamic to the research.

How does one cope with research in the time of Covid-19, which has caused many, like myself, to take an unwanted hiatus and has presented an unprecedented barrier for many Ph.D. students. Covid-19 is the epitome of uncertainty, offering an opportunity for novel research, experiences, and insights giving fresh perspectives in which to address research, like my own. The dichotomy of research in the time of Covid-19 is ever present as it continues to be a time of massive disruption, but also potential and flexibility, a time when Ph.D. students in China must learn how to be researchers in the time of Covid-19.

\section{The Impact of Covid-19 on My Planned Winter Vacation Academic Schedule (Sphiwe Wezzie Khomera)}

During my first semester course, I submitted a write-up for one of my classes, and I was determined to improve on the write-up and upgrade it to an article and then submit to a journal for possible publication during the winter vacation. However, my plans changed with the Covid-19 outbreak in China. When the disease started, I thought it was just like any type of flu outbreak. But as the month of January progressed, the situation became serious, and death toll started to increase. News reports on the number of affected cases and the death rate got me panicked and worried. Covid-19 was labeled a dangerous disease without a cure; at the time, scientists were not even sure about its mode of transmission. Numbers of infected cases kept swelling every day, and the death toll skyrocketed. I was left wondering, why me? Others who came before me studied successfully and returned home with no stigma, but I was caught in the middle of the outbreak. To make matters worse, the university imposed a lockdown on students 
living on campus and prevented us from even visiting our country-mates in other dormitories on the same campus. This move drowned my hope and academic energy and replaced them with fear and stress.

This resulted in self-quarantine in my $3 \times 3$ meter room spending days and nights on my phones talking to relatives and getting comforting words from them. Sometimes, just to spend time, I aimlessly watched movies without even knowing their titles. As days went by, my worries and anxiety got worse, I was engulfed by fear, and the wish to return home grew stronger. My academic enthusiasm I once had was washed away and replaced with uncertainties and fear of losing the academic year, as well as my life. The worst moment was when my roommate packed her bags and returned to her country at a period when the number of cases across China was around 4000 per day. I lost hope and was unable to open my computer for days. I could barely eat, not to mention doing any academic work. To make matters worse, two people were diagnosed with the flu on campus. This sent a wave of panic among international students, and I was particularly hit by this news. I spent days without leaving my room or talking to anybody in my dormitory. My plans of writing the article faded away. Even the idea of doing a background check on education policies in my country to identify a possible research gap that I could use to design my research topic was put on hold. While the virus was ravaging Wuhan, the epicenter, it was equally damaging my academic stamina and determination.

During peak period of the disease, Beijing Normal University was like a ghost city. One day, I came out of my room to get some fresh air and decided to walk around for a while. The whole campus was quiet and empty, and the only thing I could see and hear were my own footsteps. When I returned to my room, I was devastated and I expected to lose my scholarship and be sent home.

Inability to engage in any tangible academic activity during the winter break has interrupted my academic calendar. I failed to submit a possible thesis title to my supervisor, so I was behind schedule. I was equally unable to write my proposed article or do any advance reading on possible coursework for the second semester. I was unable to concentrate, knowing that the virus was dangerous and had no cure. I was worried about being unable to fulfill my academic dreams based on rumors spreading about the infection rate among students. Adoption of online classes by the University has relieved my worries and fears for being delayed.

\section{The Impact of the Covid-19 on International Education (Amina Laimeche)}

Due to this severe outbreak, on January 27th, an official statement has been released from the Beijing Normal University, and the government has had new regulations put in place. Regarding teaching and learning, this outbreak obliged everyone to stay at home, and put stress on teachers to find out new learning tools. I would say it pushes us to a new learning era; e-learning keeps people, students, and teachers on pace with their studies, works, and their research. It also supports parents in homeschooling opportunities, taking advantage of stress relief, and spending more time with the family. For me, e-learning is an opportunity to develop more skills from and out of my institute.

Second year Ph.D. students like me, who are supposed to start their data collection, are stuck in a haze of uncertainty. My research is centered around Chinese teacher education. I had planned to take a role, along with my supervisor, in class observation 
and group interviews. Timeframe for this semester was planned in detail, taking into consideration additional actions in case of inability to implement original plans. However, the outbreak of Covid-19 put me in a state of questioning. Other researchers might find it possible to conduct their research through alternative options such as online interviews. However, those of us who need to go through observation and interaction with participants, like myself; need to wait for the end of the pandemic. My research is designed around a certain case study that takes place only once each year. It cannot be brought online because teachers and students need to be observed and interviewed during and after practical courses. After receiving news about school closures and class delays, I can only postpone my research to an uncertain time in the future. My plans to complete this Ph.D. journey in 3 years will be extended by this postponement.

The impact of this outbreak did affect not only our research plans or academic life but also our mental strengths for some who are not used to isolation, like myself. The rise of cases in and out of china and social distancing created in us a fear of the unknown in the near future and made us in an endless blue, full of uncertainties.

Uncertain of the near future situation, away from family and friends has an influence on the daily functioning and learning process. I would say, for a period, found myself unable to concentrate or progress any further. But as the semester starts, online classes brought back a glance of life again and interaction; the blue that I was once in slowly faded away and back to normal. Though this pandemic is taking way longer, the Chinese government, Ministry of Health, and the international health organizations are working together to figure out how to combat this outbreak, and we can only pray and hope that this epidemic will be over soon.

\section{Coping Strategies in Chinese International Higher Education}

\section{Public Health Emergencies and National Education (Shuchen Zhou)}

China's collective memory in 2020 began with anxiety, restriction, and isolation. When did you begin to fully understand Covid-19? A student from northwest China stated as follows:

I was not concerned about the virus outbreak when the news came online. When I heard about the Wuhan's lockdown on January 23 and the government's introduction of the relevant policies, my attitude changed. I was also heartbroken when I saw the picture of Mr. Nanshan Zhong sleeping on his way to Wuhan to prevent the spread of the infectious disease. When I focused my attention on the daily rise of the confirmed cases, I felt scared.

Walter Lippmann said that in our information age, people are unable to feel every related emotion personally; they can only rely heavily on the reproduction of social reality by mass media (Wang 2019). In the Covid-19 outbreak, negative events repeated, and people's emotions were 'contagious'. With the shutdown, the spread has continued. A large number of people were infected, and the lack of rescue materials exacerbated the disaster and also heightened the overwhelming effect of press media. 
After emergent public health events, accurate collection, monitoring, and publication of data are particularly important to the public's rational judgment. Primary health knowledge possessed by individuals did not reduce the impact of the epidemic yet it expanded the national sentiment under the spread of public discourse. Insufficient understanding and speculation have caused public panic, which has continued to bring about irrational behaviors such as fear, rumors, looting materials, violence, and conflict. This may be due to the lack of perceptions about public health education.

Formation of social groups concerned about general interests in the public sphere forms a critical public opinion (Habermas 1999). In cyberspace, since the media's symbolic treatment of news as well as unchecked irrational cognition of groups, stories named 'Chinese virus', 'Wuhan virus', 'pandamonium', 'Yellow Peril', etc. have undoubtedly challenged international students. During the spread of Covid-19, students interviewed from Russia, UK, Israel, Italy, and Germany said they had been involved in verbal and physical conflict to various extents (CCYL 2020).

Rapid emergence of public health education has affected international education, mobility, and cognition. Following MERS, SARS, Ebola, Zika, Covid-19, and other epidemics, people should realize that viruses co-exist with nature. With proper health education, the public needs to take steps under the correct guidance. Now is the time to popularize international public health education all over the world. This is not the time for non-systematic separation and differentiated treatment. All countries may need to integrate public health issues into basic education from the perspective of consciousness and action.

\section{Managing International Education in Peculiar Environment (Moses Oladele Ogunniran)}

Risk and survival go hand in hand in human history. Early humans lived short and brutal lives, as the search for food and shelter exposed them to physical dangers from preying animals, poor weather, war, and outbreak of different diseases. Risk clearly is inevitable, but what does it mean to manage risk?

In December 2019, an outbreak of severe acute respiratory syndrome coronavirus 2 (SARS-CoV-2) infections was detected in Wuhan, China. In the beginning, morbidity of Covid-19 has been low, but it soon reached a tipping point in midJanuary 2020. During the second half of January, a remarkable increase of infected patients in affected cities occurred outside Hubei province because of an increase in traveling before lunar Chinese New Year. Followed by an exponential growth, the outbreak spread to other countries, attracting extensive attention around the world. Evidence of clusters of infected family members and medical workers confirmed human-to-human transmission by droplets, contact, and fomites. So far, there is no definite evidence for intrauterine infection. According to current estimates, Covid-19 has a median incubation period of 3 days (range 0 to 24 days), with potential asymptomatic transmission.

On February 18, 2020, about 380 cases were reported in Beijing, where I live. Some university students were infected, causing fear among students and staff residing in and out of campus. Many overseas Chinese students traveled home during the festive period, and were unable to return to their schools. Chinese 
students studying in New Zealand, for example, were unable to return to school due to customs regulations.

International education significantly improved through effective risk management. Which controlling or management mechanisms, theories, or models, could best manage potential risks of the Covid-19 while maintaining safety and continuity of education internationally? Perhaps, China could offer answers to some of these questions.

\section{China's International Education Governance During the Spread of Covid-19 (Man Zhang)}

The Government response to major public health emergencies always arrives with a slight temporal lag; in the field of education, this lag is even more prominent. I first heard about the new coronavirus at a seminar in late December 2019, where one of my classmates from Hubei told us that a new virus is quietly invading Wuhan, but people who released the news were punished for 'rumor charges' (later, it was proven that China missed the best time to control the new coronavirus). At that time, my classmate worried that history will repeat itself, like in the 2004 SARS epidemic, and that we will not come back to school in the next semester. Her words came true.

At 10:00, January 23, 2020, the whole Chinese nation entered a quarantine, and national and international education governance began to play a vital role in mitigating the crisis.

China's international education governance manifests in two main aspects: incoming students (including foreign student management), and outcoming students (including overseas student management). Through a combination of official documents (such as policy documents, notices, news, etc.) and my personal feelings and experiences, I distill following characteristics of China's international education governance model:

1. Educational governance philosophy. China regards the epidemic as a systematic battle, and the progress of international education governance is a must-win. As President Xi Jinping noted, 'resolutely wins the war of prevention and control of the epidemic situation, strikes and wins the war in the education system'.

2. Goals and Objectives. Ensure the heath of students, maintain normal functioning of international education, and improve quality of education.

3. Subject. Ministry of Education plays a vital role during this period. New government institutions like the Office of the Leading Group of the Ministry of Education, the Chinese Service Center for Scholarly Exchange, and Chinese Scholarship Council, play an essential role in international education governance during the epidemic.

4. Object. China is a centralized state with a 'top-down' policy working model, so international education will impact provinces, schools, teachers, students, faculty members, and universities.

5. Links. International education governance covers primary, secondary, and higher education, including enrollment, education, employment, and further education. China also values civic education in this process.

6. Method. China's international education is governed mainly through issuing documents, notification and notices, news, and so on. 


\section{Some Early Lessons}

\section{Enlightenment of Human Nature in Coronavirus Crisis for International Education (Zheng Wener)}

Since January 2020, coronavirus has caused a major public crisis. Every Chinese person is affected, in China and abroad. Since lockdown, local people regard outsiders as potential virus carriers, especially people living in Wuhan and even Hubei, many of whom have been blown out of their accommodation and spent the Spring Festival in their parked cars until the government installed them for isolation.

It is astonishing to watch discrimination against Chinese people just because the virus originated in China. Thus, Covid-19 intensifies divisions within human beings. It seems to be a part of human nature to defend those who belong to one's own faction and attack those who do not. Why cannot we just acknowledge differences with reason? As the old proverb says, there are no two identical leaves in the world. When we face a person, we should eliminate symbols imposed on them by social norms so that we can see his or her soul.

Prejudices exposed by the epidemic are common in interpersonal communication, especially among people from different countries, even in the field of education. They choose to use the imaginary national image to define the face of the peer, rather than to understand others and, in return, foster a broader understanding of a nation. In international education, students should be encouraged to express themselves truthfully. A student's personal opinion should be based on his or her experiences, not on propaganda. Listening and then judging is a responsible way to overcome the conflict brought by the unknown, just like asking the diaspora can ease the anxiety of keeping distance.

\section{Response and Reflection on Global Emergency in Education (Rulin Xu)}

Unlike traditional spring festivals, which are always full of joy, this year's holiday was full of loneliness and anxiety because of the sudden outbreak of Covid-19. As a graduating student, I returned home during vacations, and my supervisor said we would end a time-critical project soon after the spring festival. But this is now delayed, and my planned summer international exchange project has become unrealistic. However, that does not mean I am at a complete rest, because curriculum arrangements from establishing contact groups to using online teaching platforms are now in place. This may indicate that the epidemic will not end in a short time.

Many young people on social media said that they played the role of educators in their relationship with their parents, by persuading them to draw attention to the virus and take protective measures. In my family, this role is not obvious. My Mom, who worked to fight SARS 17 years ago, is very alert to the news. She carefully recalled her trips from past few days and strictly disinfected the family - she even stopped the family from eating together. TV shows have become our entertainment, but my mother soon did not want to watch them because rates of infection and death were constantly updated in the lower third of 
the screen, which made her very nervous. I played some psychological games to remove the focus from the epidemic and kept reminding her that staying at home is a very effective measure of protection. In contrast to most children persuading parents to draw attention to the virus, I have assumed a stress-relieving role in my family.

As an emerging Internet market, China was not caught off-guard by online education. Almost all courses, including swimming lessons, have been transferred online. Yet many courses use different platforms, and I have heard that many of my classmates want to return to school as soon as possible because the efficiency of learning from home is quite low. Many also said that it is nearly impossible to focus at home, and that there is nothing better than face-to-face academic activities.

\section{Conclusion (Moses Oladele Ogunniran)}

What is a truthful way to tell a story? Why, and how, does the story of student experiences of the Covid-19 pandemic matter in humanity's collective quest for appropriate emergency measures and long-term solutions? Since November 2019, public health organizations (including World Health Organization) and the media have made huge efforts to deal with the outbreak. Yet people living in China, especially Wuhan Province, are nevertheless severely affected. Lockdown, school closures, business closures, trade closures... almost everything is stopped or significantly slowed down. The Chinese government has made many strategic innovations and policies in tackling the pandemic; for schools and universities, that means transferring teaching and learning online.

In this autoethnographic article, 15 graduate students at Beijing Normal University have shared their views, experiences, and feelings, about challenges and opportunities for China's International Higher Education, in the midst of the Covid-19 pandemic. The article offers reflections on Covid-19 and Chinese International Education, experiences of online teaching and learning, reflections on university's coping mechanisms, an account of realities and feelings related to changes in academic life, and discussion on coping strategies in Chinese international higher education. Contributors write about their individual feelings, effects, benefits, challenges, and risk management strategies, as they experienced them in the pandemic. The article portrays links between students' academic and personal goals; government measures such as self-isolation, travel bans, and quarantine; realities of staying at home, and their relationships with various factors from cultural settings to class; and strong personal feelings caused by the pandemic.

'The Covid-19 pandemic has brought a huge social experiment into our homes, streets, cities, countries, and globally. Outcomes of this social experiment will follow the whole humankind, probably fairly unequally, far into the future.' (Jandrić 2020) While this article can hardly answer many questions posited by the pandemic which still rages at the time of writing, the presented testimoniesbrutal, honest, and written in the heat of the moment-will surely contribute to deeper discussions awaiting the whole world after the end of the crisis. 


\section{Open Review 1}

\section{Unique Identities and Shared Experiences with Covid-19 (Liz Jackson)}

'China's Internationalized Higher Education during Covid-19: Collective Student Autoethnography' provides an important service to readers, giving a snapshot of the tumultuous and dynamic experiences of individuals involved in international higher education in China during the Covid-19 pandemic. While initial experiences with Covid-19 took place in China, people around the world have been now impacted as the pandemic has reached global proportions. Based in Hong Kong and originally from the USA, I have often compared my experiences of being impacted by Covid-19 with those of family and colleagues in western countries. While many people face the same basic predicaments no matter where they are, at the same time differing conditions and personal particularities, of identity and perspective, make a difference. This article thus effectively highlights both unique experiences and shared ones with Covid-19 in China, at the same time revealing fascinating paradoxes of the struggle to cope with Covid-19 in the context of international higher education.

Unique identities are displayed effectively in the article, which does not seek a convergence of views across diverse authors of the writing, but instead enables each to communicate in their own voice, from their own experience. Some key positions here are those of the student and the educator in international higher education, as well as the place of those identifying as Chinese and as international in that context. While students and educators face different challenges, authors also reveal here different emotional responses to the 'new normal'. I particularly enjoyed reflecting reading of the emotions and attitudes felt by different authors about going online. Some express pride, about fast thinking in China, in relation to the pandemic and moving education en masse online. Others reveal early disdain for online education, followed by surprise at its possibility, for learning and connecting with others. Yet others share about having prior confidence with online learning, but shifting into uncertainty, in novel conditions. The view of doctoral students is also moving, as this group faces quite complex challenges, in terms of managing scholarly commitments and everyday life.

The context of international higher education in this piece reveals more complexity. It shows how Covid-19, as a global phenomenon, positions us as international persons in a new way. Now, to be Chinese feels like a curse to some, as a few authors observe the xenophobia pointed at Chinese people abroad today, as Covid-19 is associated with China. Yet at the same time, there is space for new pride in Chinese identity as well, as the response to Covid-19 there has been swift and effective, although this also raises questions about the value of personal liberty, from an international view. Being in Hong Kong, I resonated with such reflections, as Hong Kong faces a similar challenge, as it is accused by western people of coping with Covid-19 in an 'obedient' way, which is increasingly being recognized as an 'effective' way.

As a collective piece, this article shows that the global is experienced as particular and as emotionally complex and dynamic by each of us, as individuals. As we enter the next phases of this world event, this work can serve as a valuable 
foundation for later reflection on the role of international higher education around the world, in relation to Covid-19. I thank the authors for their courage and honesty in grappling with their places in this historical moment.

\section{Open Review 2}

\section{Postdigital Realities and Researcher Positionalities Revealed by Covid-19 (Sarah Hayes)}

Autoethnographic accounts are honest, reflexive, and often emotional discussions of personal human experience. As researcher narratives, they sit in stark contrast to prejudiced opinions, which are preconceived notions, neither based on scientific reasoning, nor even on actual experience. In these moving testimonials from international research students and staff in China, during the Covid-19 pandemic outbreak, we hear warm, individual tales of personal struggles, at the point when life and work changed beyond all recognition.

While coming to terms with suspended personal, research plans, unnatural social isolation and loneliness, anxiety and threat of bereavement, these authors describe too, confronting their own prejudices towards online teaching and learning, for the sake of their students, and themselves. They discuss searching for a convenient platform, feeling pushed into a new e-learning era, losing hope, being unable to open a computer, and finding their former academic enthusiasm simply ebbing away. Others comment on the joy of online connection, including cooking lessons that extend the realms of digital learning. These adjustments represent just some of the many complex, postdigital challenges thrown up by this global pandemic.

Each individual story reveals a powerful, diverse, 'postdigital positionality', where 'who we are' is constructed in a deeply personal, cultural, political, economic, technological, and material context (Hayes forthcoming 2020). Researchers are trained to account for their positionality, as they undertake qualitative inquiry. However, not only are the identities of authors revealed here, their Covid-19 narratives are shaped also by the decisions of their governments, their university, technologies they communicate through, and multiple media accounts of what others are experiencing, in virtual and physical spaces, simultaneously. Such is the 'postdigital condition' (Jandrić et al. 2018), where a messy, hybrid intertwining of the physical, biological, economical, and historical meets the technological, cultural, and personal.

This is illustrated through a different form of prejudice, than simply an aversion to online education. Human prejudice in a postdigital era has multiple routes for post-truth expression. Students discuss stigmatization by others after quarantine, where irrational fears fueled by social media, replace kindness. This is human bias cultivated at the intersections of biology, technology, and our material world, where digital devices meet superstition, and where physical masks chosen for health protection, become also destructive weapons of hatred and racism.

As scientific research currently holds the gaze of the world, in anticipation of a vaccine, antibody testing kits and personal protective equipment, autoethnographies of human experience may not seem of practical urgency. Yet these describe how individuals actually contribute to 'flattening the curve'. They reveal the human adhesive that 
binds our global medical effort across communities, through education and social care that reaches beyond personal fears. These new researchers in international higher education in China have bravely shared their diverse, poignant postdigital positionalities. As such, each contributes to an emerging picture of global research that will ultimately take us forward from this crisis. This is research that recognizes that science, education, and human experience are completely inseparable in our postdigital era, and that our international Covid-19 effort requires interdisciplinary collaboration across them all.

\section{References}

Altbach, P. G. (2013). Franchising-The McDonaldization of higher education. In P. G. Altbach (Ed.), The international imperative in higher education (pp. 111-113). Rotterdam: Sense. https://doi.org/10.1007 /978-94-6209-338-6 24.

Altbach, P.G., \& DeWit, H. (2017). The new nationalism and internationalisation of HE. University World News, 15 September. https://www.universityworldnews.com/post.php?story=20170914073027157. Accessed 5 April 2020.

Altbach, P. G., \& Knight, J. (2007). The internationalization of higher education: Motivations and realities. Journal of Studies in International Education, 11, 290-305. https://doi.org/10.1177/1028315307303542.

Bochner, A. P. (2002). Perspectives on inquiry III: The moral of stories. In M. L. Knapp \& J. A. Daly (Eds.), Handbook of interpersonal communication (pp. 73-101). Thousand Oaks, CA: Sage.

CCYL. (2020). What did overseas Chinese experience during the epidemic? https://mp.weixin.qq.com/s/XT_ d2Zc4yM_NUDEpmw9ZvA. Accessed 5 April 2020.

DeWit, H. (2019). Internationalization in higher education, a critical review. SFU Education Review, 12, 9-12. https://doi.org/10.21810/sfuer.v12i3.1036.

DeWit, H. (2020). Internationalization of higher education: The need for a more ethical and qualitative approach. Journal of International Students, 10(1), 1-4. https://doi.org/10.32674/jis.v10i1.1893.

Ellis, C. (2007). Telling secrets, revealing lives: Relational ethics in research with intimate others. Qualitative Inquiry, 13(1), 3-29. 10.1177\%2F1077800406294947.

Ellis, C., Adams, T. E., \& Bocher, A. P. (2011). Autoethnography: An overview. Forum: Qualitative Social Research, 12(1).

Eve, F. (2020). China's reaction to the coronavirus outbreak violates human rights. The Guardian, 2 February. https:/www.theguardian.com/world/2020/feb/02/chinas-reaction-to-the-coronavirus-outbreak-violateshuman-rights. Accessed 5 April 2020.

Habermas, J. (1999). Structural transformation of the public sphere. Shanghai: XueLin Press.

Han, S. (2020). Policy experimentation and power negotiation in China's higher education reforms. Higher Education, 79(2), 243-257. https://doi.org/10.1007/s10734-019-00407-2.

Han, S., \& Xu, X. (2019). How far has the state 'stepped back': an exploratory study of the changing governance of higher education in China (1978-2018). Higher Education, 78(5), 931-946. https://doi. org/10.1007/s10734-019-00378-4.

Hayes S. (forthcoming 2020). Postdigital Positionality: Developing powerful narratives for learning, teaching, research and policy in higher education. Leiden: Brill.

Heilmann, S., \& Perry, E. J. (2011). Mao's invisible hand: The political foundations of adaptive governance in China. Cambridge, MA: Harvard University Asia Center.

Jandrić, P. (2020). Postdigital research in the time of Covid-19. Postdigital Science and Education, 2, 233238. https://doi.org/10.1007/s42438-020-00113-8.

Jandrić, P., Knox, J., Besley, T., Ryberg, T., Suoranta, J., \& Hayes, S. (2018). Postdigital science and education. Educational Philosophy and Theory, 50(10), 893-899. https://doi.org/10.1080 /00131857.2018.1454000.

Knight, J. (1993). Internationalization: Management strategies and issues. International education magazine, $9(6), 21-22$.

Knight, J. (2004). Internationalization remodeled: Definition, approaches, and rationales. Journal of Studies in International Education, 8, 5-31. https://doi.org/10.1177/1028315303260832. 
Knight, J. (2012). Concepts, rationales, and interpretive frameworks in the internationalization of higher education. In D. K. Deardorff, H. DeWit, J. D. Heyl, \& T. Adams (Eds.), The SAGE handbook of international higher education (pp. 27-42). Thousand Oaks, CA: SAGE. https://doi.org/10.4135 /9781452218397.n2.

Kuhn, T. S. (1962/2012). The structure of scientific revolutions: 50th anniversary edition (4th ed.). Chicago: The University of Chicago Press.

Lim, K. F. (2017). State rescaling, policy experimentation and path dependency in post-Mao China: A dynamic analytical framework. Regional Studies, 51, 1580-1593. https://doi.org/10.1080 /00343404.2017.1330539.

Marinoni, G., \& DeWit, H. (2019). Internationalization of higher education in the new political climate. Inside Higher Education, 9 May. https://www.insidehighered.com/blogs/world-view/internationalization-highereducation-new-political-climate. Accessed 5 April 2020.

Ministry of Education of the People's Republic of China. (2019a). Statistics of Chinese students studying abroad in 2018 . http://www.moe.gov.cn/jyb_xwfb/gzdt_gzdt/s5987/201903/t20190327_375704.html. Accessed 5 April 2020.

Ministry of Education of the People's Republic of China. (2019b). Statistics of foreign students studying in China in 2018. http://www.moe.gov.cn/jyb_xwfb/gzdt_gzdt/s5987/201904/t20190412_377692.html. Accessed 5 April 2020.

Ministry of Education of the People's Republic of China. (2020a). A letter from the ministry of education to university students nationwide. http://www.moe.gov.cn/jyb_xwfb/gzdt_gzdt/s5987/202002 /t20200203_417626.html. Accessed 5 April 2020.

Ministry of Education of the People's Republic of China. (2020b). Notice on the work arrangements of "suspension of school" during the extension of primary and secondary schools [White paper]. http://www. moe.gov.cn/srcsite/A06/s3321/202002/t20200212_420435.html. Accessed 5 April 2020.

National Health Commission of the People's Republic of China. (2020). Wuhan's makeshift hospitals close after last patients are discharged. http://en.nhc.gov.cn/2020-03/10/c_77596.htm. Accessed 5 April 2020.

Tufekci, Z. (2020). How the coronavirus revealed authoritarianism's fatal flaw. The Atlantic, 22 February. https://www.theatlantic.com/technology/archive/2020/02/coronavirus-and-blindnessauthoritarianism/606922/. Accessed 5 April 2020.

Van Der Wende, M. (2001). Internationalisation policies: About new trends and contrasting paradigms. Higher Education Policy, 14(3), 249-259. https://doi.org/10.1016/S0952-8733(01)00018-6.

Wang, X. (2019). Reflection on the scientific authority of PISA's influence - an analysis based on the perspective of media research. Tsinghua Journal of Education, 40(5), 91-96.

World Health Organization. (2020). Coronavirus disease 2019 (COVID-19) situation report? 62. https://www. who.int/docs/default-source/coronaviruse/situation-reports/20200322-sitrep-62-Covid-19.pdf?sfvrsn= f7764c46 2. Accessed 5 April 2020.

Yang, R., Vidovich, L., \& Currie, J. (2007). "Dancing in a cage": Changing autonomy in Chinese higher education. Higher Education, 54, 575-592. https://doi.org/10.1007/s10734-006-9009-5.

Zha, Q. (2003). Internationalization of higher education: Towards a conceptual framework. Policy Futures in Education, 1(2), 248-270 https://doi.org/10.2304/pfile.2003.1.2.5.

Zha, Q. (2012). Is there an emerging Chinese model of the university? In R. Hayhoe, J. Li, J. Lin, \& Q. Zha (Eds.), Portraits of 21st century Chinese universities (pp. 451-471). Dordrecht: Springer. https://doi. org/10.1007/978-94-007-2789-2_15.

Zheng, J., \& Kapoor, D. (2020). State formation and higher education (HE) policy: An analytical review of policy shifts and the internationalization of higher education (IHE) in China between 1949 and 2019. Higher Education. https://doi.org/10.1007/s10734-020-00517-2.

\title{
Affiliations
}

\author{
Michael A. Peters ${ }^{1} \cdot$ Hejia Wang ${ }^{1} \cdot$ Moses Oladele Ogunniran ${ }^{1} \cdot$ Yingying $^{-}$ \\ Huang $^{1}$ - Benjamin Green ${ }^{1}$ - Jasmin Omary Chunga ${ }^{1}$ - Eric Atta Quainoo ${ }^{1}$. \\ Zhihong Ren $^{1}$. Stephanie Hollings ${ }^{1}$. Chunxiao Mou ${ }^{1} \cdot$ Sphiwe Wezzie \\ Khomera $^{1}$ - Man Zhang ${ }^{1}$. Shuchen Zhou ${ }^{1}$. Amina Laimeche ${ }^{1} \cdot$ Wener Zheng $^{1}$. \\ Rulin $\mathrm{Xu}^{1} \cdot$ Liz Jackson $^{2}$ - Sarah Hayes ${ }^{3}$
}


Michael A. Peters

mpeters@bnu.edu.cn

Moses Oladele Ogunniran

ogunniranmoses1985@yahoo.com

Yingying Huang

2931444956@qq.com

Benjamin Green

benbo83@gmail.com

Jasmin Omary Chunga

jasminchunga@outlook.com

Eric Atta Quainoo

equainoo767@yahoo.com

Zhihong Ren

201922010114@mail.bnu.edu.cn

Stephanie Hollings

shollings88@hotmail.com

Chunxiao Mou

springdaydawn@yeah.net

Sphiwe Wezzie Khomera

swkhomera@gmail.com

Man Zhang

zhangman2020@mail.bnu.edu.cn

Shuchen Zhou

shuchen.zhou@foxmail.com

Amina Laimeche

Tosane94@hotmail.com

Wener Zheng

201921010017@mail.bnu.edu.cn

Rulin Xu

xur112@163.com

Liz Jackson

lizjackson@hku.hk

Sarah Hayes

Sarah.Hayes@wlv.ac.uk

1 Beijing Normal University, Beijing, China

2 University of Hong Kong, Hong Kong, China

3 University of Wolverhampton, Wolverhampton, UK 